\title{
Journal of Climatology \& Weather Forecasting
}

\section{The Effects of the Erosion of Biodiversity on Culture: The Experience of Erei People in Biase Local Government Area of Cross River State Nigeria} Leonard Edadi Ukam

Department of Urban and Regional Planning, Cross River University of Technology (CRUTECH), CalabaR, Nigeria

*Corresponding author: Leonard Edadi Ukam, Department of Urban and Regional Planning, Cross River University of Technology (CRUTECH), Calabar, Nigeria, Tel: +2348055809705; E-mail: leoedadiukam@yahoo.com

Received date: January 19, 2018; Accepted date: March 23, 2018; Published date: March 30, 2018

Copyright: @ 2018 Ukam LE. This is an open-access article distributed under the terms of the Creative Commons Attribution License, which permits unrestricted use, distribution, and reproduction in any medium, provided the original author and source are credited.

\begin{abstract}
To say that the destruction of biodiversity is same as the destruction and erosion of culture is not an over statement. Many cultures, as exemplified by the study area are closely linked to the biodiversity of the area. Observation from the research have shown that some bushes are named after some species of trees animals which are commonly found in such areas. Same goes for sections of water (lakes, streams or river) as revealed by the study. The method adopted for the study was survey inferential, based on observation, interview an questionnaire. Seventeen Erei villages were used for the study and 400 questionnaires were administered. The study revealed that some of the culture practice in Erie were abandoned due to the absence of the forest resources such as trees, peculiar animals or birds which have been chased away from the because of disforestation drivers are lumbering, fishing, farming, expansion of settlement due to increase in population, tourism etc. Ethno-medicine was equally exchanged for pharmaceutical because of the absence of trees, leaves, roots and some bushes for this practice. In order to protect culture, biodiversity must be preserved and protected and the environment properly managed.
\end{abstract}

Keywords Biodiversity; Microorganisms; Landscape; Forest conservation; Modern medicine; Ecosystems

\section{Introduction}

A simple observation in this community shows that there is a very strong relationship between the environment and culture in whatever way one looks at it. Observed that the diversity of life on earth is formed not only of the variety of plants and animals species and ecosystem found in nature (biodiversity) but also by the variety of cultures, languages, religions and philosophies in human societies (cultural diversity). Suffice this to mean that there exist strong relationships between biological and cultural diversities and as such they face a common threat. It is on the basis of this that 1992 United Nations Conference on Environment and Development (UNCED) the earth summit in Rio de Janerio, Agenda 21, stated that the relationship between human and environment is highly complex and diverse and as such the biodiversity crisis should be understood on the basis of a more detailed evaluation of the interactions among a wide range of social, cultural, economic, political and ecological variables. Bioley [1] in his study on anthropology and Global Environmental Change, said that anthropologist are always concerned with the relationship between the people they studied and the natural environment and that since the late nineteenth century, the first professional anthropologist focused their research on tribal peoples who were directly dependent on natural resources for their survival. The environment could therefore not be ignored as anthropologist studied how people expiated the environment and then they asked how culture might in turn be shaped by the environment or by the nature of the human environment relationship. Tanli [2] opines that biodiversity erosion is a serious concern to indigenous peoples because of the loss of flora, fauna and microorganisms and the destruction of ecosystems are not just physical losses, but also a loss of indigenous knowledge systems, cultures, languages and identities. She therefore said that the very survival of peoples and cultures depends on how well they conserve and sustainably use the biodiversity and ecosystems in those territories. Trends in deforestation across countries can reveal challenges for conservation Jha and Bawa [3].

Among deforestation drivers identified by Benhin and Barbier [4] are economic activities such as timber extraction and agriculture expansion, whereas Ibimilua [5] identified such factors as source of food, income, ecological resources, social and cultural features as well as physical facilities like power and building materials. Whatever the reason for deforestation as opined by various researchers, Carr [6] has estimated that land use change over the last few millennia, though crude is as much as 50 percent of the area of tropical forest has been removed by human influence in Africa and 40 percent in Latin America and Asia CSAEHT 1993 in Carr [6]. Xu et al. [7] in their study on functional links between diversity, livelihoods and cultural in a Hani Swidden landscape in south west China observed a resilient functional link between the biodiversity, lively hood and culture. The above opinion is also held by Brookfield, Perkasem $[8,9]$.

The implication of this is that even the forest of Erei falls in this estimate, hence its effects on her culture. Bandara [10] believes that nature conservation efforts in most countries have achieved much results because the approach adopted were exclusively scientific, political, economic or legislative strategies for nature conservation and environmental protection are not culture based. This paper therefore seeks to explore the effects of biodiversity destruction on culture based on the bio cultural theory which maintains that all people are driven by human nature that seeks to domestic security and the future welfare of one's children. People living in small scale societies achieve this human ends cooperatively by remaining small consuming resources sustainably and resisting aggrandizing individuals who would promote security reducing growth in consumption. The objective of this study 
was to examine the extent to which the culture of Erei has been affected as a result of biodiversity erosion.

\section{Justification for the Study}

This study is important because it would, to large extent explain the reasons why some of the cultures in Erei which have direct relationship with the environment are either extinct or are gradually becoming extinct with the erosion of biodiversity. It will also be a guide to policy makers to see that an effective way of conserving biodiversity Is not by exotic and esoteric methods but the knowledge of indigenous practices.

\section{Research Method}

The land use and culture of Erei was studied through survey and observation. In the process it was discovered that the culture of Erei and their kith and kin at Abayong is tied to the environment especially the floral biodiversity. To carry out the socio cultural studies key persons were interviewed such as current village heads, traditional village chiefs, elders, farmers, women from the ten villages of Erei and the seven villages of her kith and kin at Abayong (both of which will now be referred as Erei Ise-mise (meaning Erei on both sides-east and west of the Cross River). The essence of this was to understand local institutions, governing access to natural resources, interactions among different social groups and networks, traditional medicine men and women and key deforestation drivers for landscape transformations.

\section{Usefulness of forest resources in the study area}

The people of Erei and her kith and kin - Abayong (sometimes referred to as Erei Isi-mise) are traditional people found on the western and eastern banks of the Cross River in Biase Local Government Area of Cross River State, Nigeria. They are mainly farmers cultivating various types of crops, such as yams, cocoyam's, pepper, okro, and cassava to mention these few. Some of the villages in this area that are situated close to the river combine farming with fishing. Among such fishing villages are Ibini, Abanwan, Afono, and Obum. Ibini village is the chief (leading) fishing settlement in this area.

This explanation helps us to understand how much these communities interact with the environment, especially the flora diversity. The forest offers great opportunity for both the literate group of the community to have a means of livelihood where they can earn income through farming or fishing and from the use of other forest resources such as trees (for building and for palm wine) that gives joy to the local people and makes them to socialize especially during their various festivals that follows the different seasons of the year. For

\begin{tabular}{|c|c|c|c|c|c|}
\hline S.N & Native Name & Scientific Name & Nature & The Part Used & Type of ailment it cures \\
\hline 1 & Anaegbe & & Herbs & Leaves & Headache \\
\hline 2 & Eghan - aenop & Allophylusu africanus & Tree & Bark & Cough, dizziness, and malaria. \\
\hline 3 & Ebibile & Milletia obanesis & Herbs & Leaves & $\begin{array}{l}\text { To stop bleeding and fresh injury and for head } \\
\text { ache }\end{array}$ \\
\hline 4 & Isikanni - e-gbegbang & $\begin{array}{l}\text { Spilantes filicalus(ground } \\
\text { pepper) }\end{array}$ & Herbs & Fruits & Mouth sore \\
\hline 5 & Odumene Iring & Cnestis ferrnginea & Herbs & Leaves & Dysentery \\
\hline 6 & Onang Ise & & Tree & Leaves & Chronic dysentery and stomach ache \\
\hline
\end{tabular}

example, Egbori - Edip (common to Ibini people) is celebrated in November during the rainy season when fish harvest is at its peak. Egbori - Aekpe (is celebrated in April during dry season) a period of planting of crops.

Sections of the forest are sometimes used for worship (sacred place) for the burial of wicked people (evil forest), for the planting of specific trees such as raffia palms (the swamps) some of which grows naturally. The forest is further used for timber, fuel wood, poles, and wood for charcoal making, fodder and honey. It is also used for wood as pulp, poles and fiber for furniture making. It is equally a good source of employment, foreign exchange earnings, raw materials for housing, provision of food for man and domestic animals, provision of clothing materials and also for herbal medicine. This is also in agreement with Ibimilua [5] on a causes and consequences of human induced deforestation in Ekiti State, Nigeria and those of Hitch cock 1996 in Ibimilua [5] that over 10,000 wild plants are used by tribal people and that out of these as many as 8,000 were used for medicinal purposes.

Other functions of the forest as identified by Ibimilua [5] and which is equally evident in this study area is that it protect biodiversity, protects water sheds, landscape beautification, recycling of soil nutrients, the release of oxygen in exchange for carbon dioxide as well as protection against erosion and flooding.

Furthermore, the forest protects both the flora and fauna that subsist in it as their habitat. Finally, forest in this area promotes culture and heritage and equally useful for recreation as tourism sites. The trees also are used to give names to sections of the forest (traditional nomenclature).

\section{Naming of bushes according to species of biodiversity}

A survey conducted by the researcher reveals that some bushes are named after the species of trees or vegetation found in that area. Examples of such are

- Eghort - Uvon (Elei Uvon) (raffia palm bush)

- Eghort - Omet (Native mango bush)

- Eghort - Inale (Thoras/thistle bush)

- Eghort - Igbai ( Kerosene wood bush)

- Eghort - Opase (Blackberry bush)

- Eghort - Abu (Abu cult forest/sacred forest)

- Odum - Ada - Ogbak (evil forest)

- Various trees and herbs also have their medicinal values as shown in Table 1.
- Eghort - edumgba (Buffalo bush) 
Citation: Ukam LE (2018) The Effects of the Erosion of Biodiversity on Culture: The Experience of Erei People in Biased Local Government Area of Cross River State Nigeria. J Climatol Weather Forecasting 6: 224. doi:10.4172/2332-2594.1000224

Page 3 of 5

\begin{tabular}{|l|l|l|l|l|l|}
\hline 7 & Ookpu ebia & Herbs & Leaves & Dysentery \\
\hline 8 & Ikor Osereng & Mallotus opposiforus & Herbs & Leaves & $\begin{array}{l}\text { Used as platter or bandage for dressing } \\
\text { wound }\end{array}$ \\
\hline 9 & Ughek Irim & Herbs & Leaves & Grip sickness in children \\
\hline 10 & Ugwuman & Herbs & Leaves & Headache \\
\hline 11 & Igbomonetu & $\begin{array}{l}\text { Ipomoea involucrate (morning } \\
\text { glory) }\end{array}$ & Plant & Leaves and bark & Convulsion \\
\hline 12 & Inai ekpe & $\begin{array}{l}\text { Funtumia elastic( African } \\
\text { rubber) }\end{array}$ & Plant & Leaves & Dysentery \\
\hline 13 & mbebem & Iconea collifolie & Plant & Fruits, leaves and barks & Constipation in children \\
\hline
\end{tabular}

Table 1: Showing Medicinal Values of Trees/ Herbs, Source: researcher field work, 2014.

The list is numerous but the researcher simply considered the above ailment in Erei. The implication of this is that the language of the to show the extent of traditional knowledge in the treatment of simple people is also linked up to the flora biodiversity (Table 2).

\begin{tabular}{|c|c|c|c|c|}
\hline S.N & Flora product & Source(s) & Processes before use & Effects on the body \\
\hline 1 & Oli & $\begin{array}{l}\text { Roots belonging to the } \\
\text { class of --ginger. }\end{array}$ & $\begin{array}{l}\text { Grinded until it forms paste. Broomstick is used to } \\
\text { dip into it and lines or curves of different designs } \\
\text { drawn on the body. It is allowed to dry on the body } \\
\text { for five hours and above and thereafter, scrapped } \\
\text { or peeled off the body with the finger. }\end{array}$ & $\begin{array}{l}\text { The lines/designs made with it on the body rises } \\
\text { like strokes of cane, appearing like different } \\
\text { contours like hachures, leaving the space within the } \\
\text { lines lower. }\end{array}$ \\
\hline 2 & Igbong & $\begin{array}{l}\text { There are two types: (I) } \\
\text { Tiny green seeds, looking } \\
\text { like the dung or excreta } \\
\text { (from goats found on some } \\
\text { peculiar tender trees. (II) } \\
\text { This type is in the form of } \\
\text { pod (round/oblong) like the } \\
\text { cocoa pod with the seed } \\
\text { inside. The seeds are tiny. }\end{array}$ & $\begin{array}{l}\text { The seeds, either in type }(\mathrm{I}) \text { or the extracted from } \\
\text { the pod in type (II) are grinded with a stone and } \\
\text { charcoal from firewood is added to it and water to } \\
\text { mix it to produce the black coloration on the body. } \\
\text { The indelible designs produced on the body takes } \\
\text { up to two weeks and more to be completely erased } \\
\text { from the body. }\end{array}$ & $\begin{array}{l}\text { Igbong is mainly for decoration on the body of the } \\
\text { maiden for the purpose of beautification. It is mainly } \\
\text { used by the female folk. It is superstitiously believed } \\
\text { to have efficacy to cure pains on the joints when } \\
\text { applied to such regions of the body. }\end{array}$ \\
\hline 3 & Igbot & From red cam wood & $\begin{array}{l}\text { Chippings, extracted from red cam wood } \\
\text { (mahogany) after the chippings are properly } \\
\text { grinded until it forms paste. A local brush made } \\
\text { from the fibers of coconut fruit is used in rubbing it } \\
\text { on the body of the maiden or males, exclusive cult } \\
\text { activities. Used by women mostly during their three } \\
\text { months in the fattening room in preparation for } \\
\text { marriage. It is rubbed on the whole body from the } \\
\text { face and neck down to the feet throughout the } \\
\text { period of the celebration. }\end{array}$ & $\begin{array}{l}\text { Smoothens the body and removes spots from the } \\
\text { body, thereby adding beauty to the body. }\end{array}$ \\
\hline 4 & Uwut & $\begin{array}{l}\text { From yellow color } \\
\text { mangrove tree found at the } \\
\text { coast. }\end{array}$ & $\begin{array}{l}\text { Chippings extracted from yellow wood (mangrove } \\
\text { tree) and grinded on the grinding stone until it forms } \\
\text { paste. A little water is added at interval until the } \\
\text { paste is produced. It is rubbed holistically from the } \\
\text { face and neck down to the feet. }\end{array}$ & $\begin{array}{l}\text { It has the same effect like the red cam wood. } \\
\text { Therefore, it is an alternative to cam wood in their } \\
\text { usage depending on the occasion. It is for } \\
\text { decoration and smoothening of the body. }\end{array}$ \\
\hline 5 & Esuu & $\begin{array}{l}\text { This is the only traditional } \\
\text { decorative material that is } \\
\text { not extracted from the flora } \\
\text { but from the earth white } \\
\text { native chalk. It is } \\
\text { sometimes referred to as } \\
\text { the native chalk. }\end{array}$ & $\begin{array}{l}\text { It is dug from the ground where chalk or clay is } \\
\text { found. This also has effect on the ecosystem as } \\
\text { most of the under growth plants in the area are } \\
\text { destroyed. }\end{array}$ & $\begin{array}{l}\text { Chalk is extracted from the ground in palette form } \\
\text { and grinded and mixed with water until it forms } \\
\text { paste. It is used by maidens and young men during } \\
\text { some peculiar celebration. It is also used on } \\
\text { children to provide cooling effect as a cure for some } \\
\text { ailments. It has cooling effects and it also smooth } \\
\text { the body. }\end{array}$ \\
\hline
\end{tabular}

Table 2: Showing Cultural Uses of Some Selected Flora Diversity, Source: Researcher's Field Work, 2014.

\section{Naming of Bushes}

A survey conducted by the researcher reveals that some bushes are named after common species of trees or vegetation (flora) or animals found in that area or even after cultural affinity. Example of such areas at Ibini village in Erei is as follows:
- Elei-Uvon (raffia palm bush)

- Eghort-Omet (native mango bush)

- Eghort-Inak (thorns or thistle bush)

- Eghort-Igbai (kerosene wood bush)

- Eghort-Opase (blackberry bush) 
Page 4 of 5

- Eghort-Edum-gba (buffalo bush) fauna

- Eghort-Abu (abu cult forest/sacred forest

- Odum Ada-ogbale (evil forest, named after the goddess of water for the burial of the wicked)

- Oojah (wild rice species bush)

The implication of this is that biodiversity (both flora and fauna) also influences the language of the people. This is why the segment of the population (especially the youth) who may have come after this vegetation of the species of trees or animals have become extinct do not know how this flora or fauna bushes are called, neither do they know the medicinal potency or usage of the plants.

Bandara [10] in a study, "Exploring the link between culture and biodiversity in Sri Lanka" corroborate this assertion that people's traditional ways of interacting with and comprehending their natural environment, together composes an invaluable body of traditional knowledge that underpins aspect of local agriculture, health care, food preparation, education, environmental conservation and a host of other spheres.

\section{Deforestation Drivers in the Study Area}

The study area, like most other rural areas have various deforestation drivers, chief of which is agriculture. This factor (agriculture) is even growing worse with the high rate of unemployment which has created additional increase in rural population, aside from the natural increase (by birth). The influx of school leavers from secondary schools and the tertiary institutions who find agriculture and fishing in the rural forest and waters as a ready employment while waiting for employment in the nonagricultural (non-primitive occupation) sector such as the civil and public sectors as well as the private sectors (industries and companies). Other factors or deforestation drivers are local building materials, tapping, expansion of village settlements, harvesting of leaves and other forest resources for food, medicine, trapping, boat making, lumbering etc.

\section{Cultural Deforestation Drivers}

Some cultural activities also cause deforestation. Amongst such activities are, the clearing of the section of the forest for sacred cultural activities (e.g. Abu forest), harvesting of oil palm fronds to build huts and fences during some sacred cultural festival, the harvesting of the seeds, roots, leaves and barks of some trees for decoration on the body of the maiden or young men depending on the festival as shown in the table. Also, the bamboos (branches) or raffia palms are sometimes used by young men to flog themselves (voluntarily) between two opponents to demonstrate manhood (maturity) because nobody must cry because the girls and women are watching. The festival is called "Aekpe" celebrated in April during the dry seasons.

\section{Effects on the Forest}

Each of the activities and processes mentioned above has a way of causing deforestation. For instance, the cutting down of trees has caused most of the forest areas to become secondary forest, exposing the land to erosion with a resultant poor agricultural yields. Though the villagers do not realize this so they attribute it to the annoyance of the goddess of fertility and goddess of the water where it affects fishing. Some streams have become silted because of erosion due to deforestation. Raffia palms have become almost difficult to come by because of the number of young men who have taken to tapping as a result of unemployment in the country. Culturally, the trees, roots and herbs used for decoration have become either too difficult to get (threatened) or they have become completely unavailable (extinct) or too far away from the reach of the community. Hence, such cultural practices have become completely abandoned by the traditional people. Bush burning for agriculture has caused accidental burning of reserved bushes resulting in their exposure to erosion and consequent infertility on the soil. This has equally affected the location of Esu (native chalk) that is traditionally used for the decoration of maidens and young men during cultural festival. Native chalk is also medicinally used on infants for the cure of rashes and as a cooling conditioner during hot weather condition (Table 3).

\begin{tabular}{|c|c|c|c|}
\hline S.N & Reason for some cultural festival disappearance & Frequency of respondence & Percentage \\
\hline 1 & Lack of interest on the part of celebrants. & 86 & 21.5 \\
\hline 2 & Absence of forest space for cultural practice & 86 & 21.5 \\
\hline 3 & Absence of materials for use in the bush & 70 & 17.5 \\
\hline 4 & Low patronage by visitors from other communities & 49 & 12.25 \\
\hline 5 & It is barbaric in nature/unchristian & 39 & 9.75 \\
\hline \multirow[t]{2}{*}{6} & The present generation does not know how to do it & 70 & 17.5 \\
\hline & Total & 400 & 100 \\
\hline
\end{tabular}

Table 3: Causes of the Extinction of Some Cultural Practices, Source: Researcher's Field Work, 2014.

The table above shows that lack of interest on the part of the celebrant and the absence of forest space for cultural practices ranked highest in response as the causes of the extinction of cultural activities.

\begin{tabular}{|l|l|l|l|}
\hline Estimated number of trees & Frequency of responses and percentage & Estimated distance to their location & Frequency of response/percentage \\
\hline $5-10$ & $126(31.6 \%)$ & $1 \mathrm{~km}$ & $44(11.6 \%)$ \\
\hline
\end{tabular}

The lack of interest is not unconnected with the lack of a secluded place in the forest for the activities (Table 4). 
Page 5 of 5

\begin{tabular}{|l|l|l|l|}
\hline $10-15$ & $48(12 \%)$ & $1-2 \mathrm{~km}$ & $29(7.2 \%)$ \\
\hline $15-20$ & $43(10.8 \%)$ & $2-3 \mathrm{~km}$ & $40(10.0 \%)$ \\
\hline $20-25$ & $40(10 \%)$ & $3-4 \mathrm{~km}$ & $104(26.0 \%)$ \\
\hline Above 25 & $107(26.8 \%)$ & $4-5 \mathrm{~km}$ & $68(17.0 \%)$ \\
\hline No answer & $35(8.8 \%)$ & Above $5 \mathrm{~km}$ & $115(28.8 \%)$ \\
\hline Total & $400(100 \%)$ & & \\
\hline
\end{tabular}

Table 4: Estimated Number of Trees and Estimated Distance to Their Location, Source: Researchers Field Work, 2014.

From the table above, ethno-medicine which is part of people's culture is equally affected by deforestation which has pushed most of the medicinal trees far from the traditional settlements. The effect is shown below by the frequency of the use of ethno - medicine compared to modern medicine (Table 5).

\begin{tabular}{|l|l|l|}
\hline Years & Frequency of use of ethno - medicine ( herbal) & Frequency of use of modern medicine (pharmaceutical) \\
\hline $1980-1990$ & $352(88 \%)$ & $48(12 \%)$ \\
\hline $1990-2001$ & $341(85.25 \%)$ & $59(14.75 \%)$ \\
\hline $2001-2011$ & $272(68 \%)$ & $128(32 \%)$ \\
\hline 2011 and Above & $107(26.75 \%)$ & $293(73.25 \%)$ \\
\hline
\end{tabular}

Table 5: Frequency of Use of Ethno - Medicine, Source: Researcher’s Field Work, 2014.

The above table shows the extent of destruction of indigenous medicine by the destruction of flora diversity and a shift from ethnomedicine to modern medicine (pharmaceutical) by indigenous people as the years go by.

\section{Recommendation}

To revive those friendly cultures that are meant for mere entertainment and whose activities are not barbaric, it is important to adopt traditional conservation methods such as bush fallow system of agriculture, the conservation of certain sections of the forest by traditional laws and sanctions, superstitious belief as a no go area which if violated attracts spiritual sanctions from the gods of the land. Other methods are the restrictions of some sections of the land only to initiate to the exclusion of non-initiate (male or female) and other sections to only male members of the community. This will reduce the number of people making demands on such sections of the forest.

There should be proper enforcement of native laws and order on defaulters who enters the conserved areas without permission. The enforcement could either be done by the traditional sacred societies or by the elders or title holders in the community. Establishment of industries and creation of more jobs in other sectors will offer employment to young school leavers, thereby reducing pressure on the land through agricultural practices which the unemployed school leavers falls back on as a ready employment opportunity.

\section{Conclusion}

If some of the traditional or cultural ways of conservation is adopted again, the vegetation will be conserved and it will become easy to bring back some of those cultures that are environment friendly.

\section{References}

1. Bioley JH (2002) Anthropology and Global Environmental Change. USA: Washinton State University, Pullman College pp: 1-5.

2. Tanli CV (2009) The importance of indigenous people issues secretariat of the permanent forum on indigenous issues, United Nation.

3. Jha S, Bawa KS (2005) Population Growth, Human Development and Deforestation in Biodiversity Hotspots, Conservation Biology 20: 906-912.

4. Benhin JKA, Barbier EB (2003) Structural Adjustment Programme, Deforestation and Biodiversity Loss in Ghana, Environmental and Resource Economics 27: 337-366.

5. Ibimilua Af (2012) Appraisal of the causes and consequences of Human induced Deforestation Eketi: Department of Geography and planning science, Faculty of social sciences, Ekiti State University.

6. Carr DL (2004) Tropical Deforestation. University of North Carolina, Chapel Hill pp: 293-298.

7. Xu J, Lebel L, Sturgeon J (2009) Functional links between Biodiversity, Livelihoods and Culture in a Hani Swidden Landscape in Southwest China Ecology and society 14: 1-20.

8. Brookfield HC, Padoch H, Parson M, Stocking (2003) Cultivating biodiversity: understanding, analysis and using agricultural diversity, intermediate Technology Development Group.

9. Perkasem K, Lawrence D, Padoch C, Vogt DS, Ziegler AD et al, (2009) Consequences of Swidden transitions for crop and fallow biodiversity in Southeast Asia, Human Ecology 37: 347-360.

10. Bandara CMM (2008) Exploring the link Between Culture and Biodiversity in Sri Lanka Colombo: National Atlas of Sri Lanka, Survey Department, Env. J for the Global Community 4: 1-23

This article was originally published in a special issue, entitled: "Research and Reviews on Climatology", Edited by Tianxing Wang 